\title{
SOSIALISASI PENGEMBANGAN SUMBER DAYA MANUSIA BAGI GURU PADA YAYASAN HASANAH MANGGALATAMA, TANGERANG SELATAN
}

\author{
${ }^{1 *}$ Achmad Taufik, ${ }^{2}$ Eko Yulianto, ${ }^{3}$ Ihsan Suryadi, ${ }^{4}$ Bralius Gideon Siahaan, \\ ${ }^{5}$ Hadi Supratikta \\ Universitas Pamulang, Tangerang Selatan, Banten, Indonesia

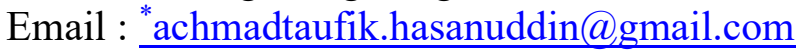

Manuskrip: Desember -2021; Ditinjau: Januari -2022; Diterima: Januari -2022; Online: Januari-2022; Diterbitkan: Januari-2022

\begin{abstract}
ABSTRAK
Tujuan umum dari kegiatan pengabdian kepada masyarakat ini adalah Memberikan sosialisasi, pengarahan serta pengetahuan ilmu manajemen dalam pengembangan sumber daya manusia bagi guru pada Yayasan Hasanah Manggala Tama Perumahan Permata Pamulang. Metode yang digunakan adalah sosialisasi dan pelatihan materi secara langsung serta diskusi mengenai penerapan MSDM dalam pengembangan sumber daya manusia bagi guru pada Yayasan Hasanah Manggala Tama Perumahan Permata Pamulang. Pengelolaan yang baik akan menghasilkan SDM yang baik dan menghasilkan SDM yang memiliki kemampuan dan keterampilan yang apik. Dengan segala permasalahan yang dihadapinya akan mempengaruhi kinerja sumber daya tersebut, baik secara fisik ataupun psikis dalam pencapaiannya kepada suatu tujuan.
\end{abstract}

\section{Kata Kunci: Manajemen, Pengembangan Sumber Daya Manusia}

\section{PENDAHULUAN}

Lembaga pendidikan Islam yang ada di Indonesia sebagai sistem pendidikan nasional yang salah satu tujuannya untuk mencetak insan yang bermutu untuk bangsa dalam segala aspeknya, terutama dalam peningkatan moral. Membangun seutuhnya manusia adalah upaya dari sebuah proses membangun bangsa, baik dalam segi moralitas ataupun materil. Namun, dalam segala proses penyelenggaraannya telah diatur sedemikian rupa oleh negara melalui proses formal, informal dan non formal.

Pada penyelenggaraan pendidikan nampaknya mendapat perhatian lebih dari pemerintah melalui pendidikan formal, yang dibagi menjadi dua yaitu sekolah umum dan madrasah, perlu digaris bawahi kedua pendidikan tersebut masuk ke dalam pendidikan formal. Pada hakikatnya kedua pendidikan tersebut mempunyai tujuan yang sama yaitu membina dan meningkatkan sumber daya manusianya (SDM) atau mutu sumber daya manusia bangsa Indonesia secara utuh demi mencapai tujuan pembangunan nasional. 
Dalam konteks pengembangan sumber daya manusia (PSDM) sangat tepat jika dikaitkan dengan proses pelaksanaan pendidikan. Demi meningkatkan sumber daya manusia yang berkualitas sangat dibutuhkan dukungan lebih, terutama dari stake holder di dalam lembaga pendidikan tersebut ataupun orang-orang yang mempunyai pengaruh di lembaga pendidikan. Agar tercapainya tujuan pendidikan, hendaknya pengelolaan pendidikan harus secara professional dengan manajemen yang rapi dan oleh SDM yang mempunyai loyalitas kerja yang tinggi. Seperti yang kita ketahui, pengembangan sumber daya manusia adalah salah satu prioritas pendidikan nasional, kaitannya yaitu dalam peningkatan mutu pada setiap jenis jenjang pendidikan. Bersamaan dengan kehidupan di masyarakat harus adanya pengembangan pendidikan, agar siswa dapat beradaptasi dengan perkembanan dan segala peruahan yang ada di masyarakat.

Istilah sumber daya manusia (SDM) bukan hanya digunakan dalam sebuah pekerjaan yang tidak ada kaitannya dengan dunia pendidikan, namun SDM justru diciptakan melalui lembaga pendidikan yang menaruh bekal kepada peserta didiknya sebagai suber daya manusia yang bermutu demi mencapai tujuan pembangunan nasional. Sumber daya manusia (SDM) sendiri dapat didefinisikan seperti karyawan, pekerja, atau pegawai yaitu manusia yang mempunyai kontribusi dan pekerjaan langsung terhadap suatu organisasi (Ulfatin and Teguh Triwiyanto 2016:8).

Dalam setiap institusi, mutu maupun peningkatan mutu merupakan fokus terpenting yang paling terpenting. Meski begitu, anggapan sebagian orang mutu merupakan sebuah konsep yang penuh dengan teka-teki. Mutu lebih cenderung relatif dan dianggap sesuatu yang membingungkan dan rumit untuk diukur. Dalam setiap pandangan seseorang, terkadang makna mutu menjadi pertentangan dalam segi makna dan pendapat, sehingga tidak heran jika menemui beberapa orang yang tidak memiliki pemahaman dan pendapat yang sama terkait bagaimana cara menjadikan institusi yang baik (Edward Sallis 2012:21).

Yayasan Hasanah Manggala Tama adalah sebuah yayasan yang bergerak di tiga bidang yaitu bidang sosial, pendidikan, dan agama. Yang mana kegiatan ini kami bangun untuk kepentingan masyarakat yang sangat membutuhkan, sama halnya dengan kegiatan kerelawanan untuk membangun sebuah pendidikan kemudian sosial dan juga agama. Yayasan Hasanah Manggala Tama Perumahan Permata Pamulang, Tangerang Selatan pada sektor pendidikan adalah salah satu yang menerapkan sistem boarding untuk para siswanya dan diawasi langsung oleh guru-guru ataupun pembimbing yang menjadi penanggung jawab boarding dan pimpinan yang menjadi yang menjadi pusat kebijakan di dalamnya.

Dalam pengembangan sumber daya manusia di Yayasan Hasanah Manggala Tama Perumahan Permata Pamulang yakni melalui perekrutan tenaga pendidik yang harus melalui seleksi yang diselenggarakan oleh yayasan dan pimpinan pondok setelah melaksanakan seleksi-seleksi yang telah dilakukan sebelumnya. Setelah melewati beberapa seleksi maka calon tenaga pendidik akan diberitahu tentang hasil seleksi yang telah dilewatinya lalu menjalani kontrak masa training selama 3 (Tiga) bulan dan akan mendapatkan penilaian selama masa training dan 
akan diberikan keputusan lanjut setelah 3 (Tiga) bulan masa training kemudian akan diperpanjang masa kontrak selama minimal 1(Satu) tahun jika kinerja tenaga pendidik dianggap baik oleh yayasan.

\section{METODE PELAKSANAAN KEGIATAN}

Metode pelatihan yang diterapkan berdasarkan solusi atas permasalahan di Yayasan Hasanah Manggala Tama Perumahan Permata Pamulang, Tangerang Selatan. Pengabdian Kepada Masyarakat (PKM) akan dilaksanakan di Yayasan Hasanah Manggala Tama Perumahan Permata Pamulang, Tangerang Selatan pada bulan November 2021.

Pelatihan yang dirancang untuk mengembangkan sumber daya manusia melalui rangkaian kegiatan identifikasi, penyuluhan serta proses pelatihan yang terencana. Untuk mengatasi permasalahan yang ada, tim akan melakukan pelatihanpelatihan bagi seluruh guru Yayasan Hasanah Manggala Tama Perumahan Permata Pamulang.

Jenis luaran yang akan dihasilkan dari masing-masing solusi yaitu memberikan sosialisasi, pengarahan serta pengetahuan ilmu manajemen dalam pengembangan sumber daya manusia bagi guru pada Yayasan Hasanah Manggala Tama Perumahan Permata Pamulang agar para guru dapat lebih termotivasi, semangat dan inovatif dalam melaksanakan kegiatan belajar mengajar serta dapat lebih disiplin waktu dan menambah wawasan para guru dalam bidangnya masingmasing. Metode Kegiatan: Penyuluhan, Diskusi dan tanya jawab seputar manajemen dalam pengembangan sumber daya manusia.

\section{HASIL DAN PEMBAHASAN}

Lembaga pendidikan Islam yang ada di Indonesia sebagai sistem pendidikan nasional yang salah satu tujuannya untuk mencetak insan yang bermutu untuk bangsa dalam segala aspeknya, terutama dalam peningkatan moral. Membangun seutuhnya manusia adalah upaya dari sebuah proses membangun bangsa, baik dalam segi moralitas ataupun materil. Namun, dalam segala proses penyelenggaraannya telah diatur sedemikian rupa oleh negara melalui proses formal, informal dan non formal.

Pada penyelenggaraan pendidikan nampaknya mendapat perhatian lebih dari pemerintah melalui pendidikan formal, yang dibagi menjadi dua yaitu sekolah umum dan madrasah, perlu digaris bawahi kedua pendidikan tersebut masuk ke dalam pendidikan formal. Pada hakikatnya kedua pendidikan tersebut mempunyai tujuan yang sama yaitu membina dan meningkatkan sumber daya manusianya (SDM) atau mutu sumber daya manusia bangsa Indonesia secara utuh demi mencapai tujuan pembangunan nasional.

Dalam konteks pengembangan sumber daya manusia (PSDM) sangat tepat jika dikaitkan dengan proses pelaksanaan pendidikan. Demi meningkatkan sumber daya manusia yang berkualitas sangat dibutuhkan dukungan lebih, terutama dari stake holder di dalam lembaga pendidikan tersebut ataupun orang-orang yang mempunyai pengaruh di lembaga pendidikan. Agar tercapainya tujuan pendidikan, 
hendaknya pengelolaan pendidikan harus secara professional dengan manajemen yang rapi dan oleh SDM yang mempunyai loyalitas kerja yang tinggi. Seperti yang kita ketahui, pengembangan sumber daya manusia adalah salah satu prioritas pendidikan nasional, kaitannya yaitu dalam peningkatan mutu pada setiap jenis jenjang pendidikan. Bersamaan dengan kehidupan di masyarakat harus adanya pengembangan pendidikan, agar siswa dapat beradaptasi dengan perkembanan dan segala peruahan yang ada di masyarakat.

Fungsi manajemen sumber daya manusia adalah agar dapat meningkatan mutu lembaga pendidikan agar dapat menghasilkan output pembelajar yang bermutu dan memperoleh pendidikan yang lebih baik untuk masyarakat. Maka dari itu manajemen sumber daya manusia pendidikan sangat penting dalam peningkatan lembaga pendidikan. Dalam setiap institusi, mutu maupun peningkatan mutu merupakan fokus terpenting yang paling terpenting. Meski begitu, anggapan sebagian orang mutu merupakan sebuah konsep yang penuh dengan teka-teki. Mutu lebih cenderung relatif dan dianggap sesuatu yang membingungkan dan rumit untuk diukur. Dalam setiap pandangan seseorang, terkadang makna mutu menjadi pertentangan dalam segi makna dan pendapat, sehingga tidak heran jika menemui beberapa orang yang tidak memiliki pemahaman dan pendapat yang sama terkait bagaimana cara menjadikan institusi yang baik (Edward Sallis 2012:21).

Yayasan Hasanah Manggala Tama adalah sebuah yayasan yang bergerak di tiga bidang yaitu bidang sosial, pendidikan, dan agama. Yang mana kegiatan ini kami bangun untuk kepentingan masyarakat yang sangat membutuhkan, sama halnya dengan kegiatan kerelawanan untuk membangun sebuah pendidikan kemudian sosial dan juga agama. Yayasan Hasanah Manggala Tama Perumahan Permata Pamulang, Tangerang Selatan pada sektor pendidikan adalah salah satu yang menerapkan sistem boarding untuk para siswanya dan diawasi langsung oleh guru-guru ataupun pembimbing yang menjadi penanggung jawab boarding dan pimpinan yang menjadi yang menjadi pusat kebijakan di dalamnya.

Dalam pengembangan sumber daya manusia di Yayasan Hasanah Manggala Tama Perumahan Permata Pamulang yakni melalui perekrutan tenaga pendidik yang harus melalui seleksi yang diselenggarakan oleh yayasan dan pimpinan pondok setelah melaksanakan seleksi-seleksi yang telah dilakukan sebelumnya. Setelah melewati beberapa seleksi maka calon tenaga pendidik akan diberitahu tentang hasil seleksi yang telah dilewatinya lalu menjalani kontrak masa training selama 3 (Tiga) bulan dan akan mendapatkan penilaian selama masa training dan akan diberikan keputusan lanjut setelah 3 (Tiga) bulan masa training kemudian akan diperpanjang masa kontrak selama minimal 1(Satu) tahun jika kinerja tenaga pendidik dianggap baik oleh yayasan.

1. Pemberian penyuluhan sosialisasi bagi guru pada Yayasan Manggala Tama Perumahan Permata Pamulang agar terwujudnya pengembangan pada sumber daya manusia pada yayasan tersebut khususnya bagi guru, sehingga yang dapat diperoleh adalah:Termotivasi tenaga pengajar agar lebih semangat dan inovatif dalam melakukan kegiatan belajar mengajar.

2. Bertambahnya wawasan tenaga pengajar dalam bidangnya masing-masing. 
3. Tenaga pengajar dapat lebih disiplin dan lebih dapat mengatur manajemen waktu dalam proses belajar mengajar.

\section{KESIMPULAN}

Mengadakan Pengabdian Kepada Masyarakat dalam penyuluhan sosialisasi terhadap manajemen dalam pengembangan sumer daya manusia bagi guru, dalam uapaya mewujudkan kualitas guru yang lebih inovatif, berwawasan luas serta disiplin waktu. Pada Pengabdian Kepada Masyarakat setelah kegiatan penyuluhan, pelatihan dan pendampingan kepada guru Yayasan Hasanah Manggala Tama Perumahan Permata Pamulang yaitu dengan cara mengisi instrument yang disiapkan oleh TIM PKM terkait bagaimanakah tanggapan para karyawan dan tenaga pengajar terhadap kegiatan PKM yang dilakukan oleh Tim PKM Pasca Sarjana Manajemen Universitas Pamulang.kegiatan ini diharapkan dapat mendorong para guru untuk termotivasi untuk lebih semangat dan inovatif dalam melaksanakan kegiatan belajar mengajar maka harus dilakukan pelatihan dan penyuluhan secara berkala, agar seluruh elemen Yayasan Hasanah Manggala Tama dapat bekerjasama dalam mengembangkan sumber daya manusia guna menciptakan suasana kegiatan belajar mengajar yang lebih inovatif, berwawasan luas serta disiplin waktu pada Yayasan Hasanah Manggala Tama Perumahan Permata Pamulang, Tangerang Selatan, agar para guru dapat tetap konsisten dan selalu termotivasi dan semangat dalam melaksanakan kegiatan belajar mengajar maka harus tetap dilakukan pendampingan dan evaluasi dari pihak yayasan terhadap para guru.

\section{DAFTAR PUSTAKA}

Arikunto, Suharsimi. 1989. Prosedur Penelitian Suatu Pendekatan Praktek. Jakarta: Bima Aksara.

Benny, Cornelia J. 2005. "Manajemen Sumber Daya Manusia Di Perguruan Tinggi." Jurnal Administrasi Pendidikan Vol. 3 (No. 2)

Edward Sallis. 2012. Manajemen Mutu Terpadu Pendidikan. Yogyakarta: IRCiSoD.

Edy Sutrisno. 2013. "Manajemen Sumber Daya Manusia.” In . Jakarta: Kencana Prenada Media Group.

Haikal, H., et al. (2021). Penyuluhan Pemanfaatan Media Sosial Bagi Perkembangan Sumber Daya Manusia (SDM) Pada Masyarakat Desa. Jurnal PADMA: Pengabdian Dharma Masyarakat, 1(3).

Hasibuan. 2005. "Optimalisasi Manajemen Sumber Daya Manusia Dalam Upaya Peningkatan Mutu Sekolah.” Jurnal Pendidikan Dasar Vol. 12 (No. 2).

Sagala, Syaiful. 2006. Administrasi Pendidikan Kontemporer. Bandung: Alfabeta. Sugiyono. 2014. Memahami Penelitian Kualitatif. Bandung: Alfabeta. 